\title{
Effect of oregano oil dietary supplementation on production parameters, height of intestinal villi and the antioxidant capacity in the breast of broiler
}

\author{
Ivette Fonseca-García ${ }^{a}$, Francisco Escalera-Valente ${ }^{a}$, Sergio Martínez-González ${ }^{\mathrm{a}}$, \\ Carlos A. Carmona-Gasca ${ }^{a}$, Diana A. Gutiérrez-Arenas ${ }^{\mathrm{b}}$, Fidel Ávila-Ramos ${ }^{\text {** }}$
}

\begin{abstract}
Oregano additives could contain growth stimulating compounds for poultry, however, a great variation attributed to their main components is observed. The aim of the present study was to investigate the effect of oregano oil dietary supplementation on the productive variables, the height of the intestinal villi and the accumulation of antioxidant compounds in the breast of broilers. In total, 480 broilers were reared from 1 to $42 \mathrm{~d}$ of age and since the first day of life were allocated into four treatments, each with four replications of 30 birds. The formulated diet was based on corn and soybean meal and 0, 100, $200 \mathrm{or} 400 \mathrm{mg}$ of oregano oil per $\mathrm{kg}$ of feed were incorporated in the diets of treatment 1,2,3 and 4, respectively. Feed intake, weight gain, feed conversion and mortality rates were weekly recorded. At 21 and 42 days of age the intestinal villi height and antioxidant capacity in the chicken breast were measured. Oregano oil used contained $43.17 \%$ and $29.16 \%$ of thymol and carvacrol, respectively. Feed intake, weight gain, feed conversion rate and mortality were not affected by oregano oil dietary supplementation. The height of intestinal villi increased with the level of oregano oil supplementation $(P<0.05)$. However, the size of the intestinal villi was greater in the duodenum compared to the other parts $(P<0.05)$, and jejunum and ileum had the same height. Antioxidant capacity of chicken breast at the 6th week was increased in the group that was dietary supplemented with $400 \mathrm{mg}$ of oregano oil per $\mathrm{kg}$ of feed.
\end{abstract}

Key words: thymol, carvacrol, DPPH, natural additive.

RESUMEN. El aceite de orégano contiene aditivos que pueden estimular el crecimiento de las aves, sin embargo presenta gran variación atribuida a sus principales compuestos. El objetivo del estudio fue determinar el efecto del aceite de orégano en la dieta respecto de las variables productivas, altura de las vellosidades intestinales y acumulación de sus compuestos antioxidantes en la pechuga de pollo. En total, 480 pollos fueron engordados de 1 a 42 días de edad, siendo distribuidos en cuatro tratamientos, cada uno con cuatro réplicas de 30 pollos. La dieta se formuló a base de maíz y pasta de soya, adicionada con 0, 100, 200 o $400 \mathrm{mg}$ de aceite de orégano por kg de alimento. El consumo de alimento, ganancia de peso, conversión alimenticia y mortalidad se registraron semanalmente. A los 21 y 42 días de edad se midieron la altura de las vellosidades intestinales y la acumulación de compuestos antioxidantes en la pechuga de las aves. El aceite de orégano contenía $43,17 \%$ y $29,16 \%$ de timol y carvacrol, respectivamente. La ingesta de alimento, ganancia de peso, índice de conversión alimenticia y mortalidad no fueron afectados por la adición del aceite de orégano a la dieta. La altura de las vellosidades intestinales incrementó con el nivel de aceite de orégano suplementado en la dieta $(P<0,05)$, pero el tamaño de las vellosidades intestinales en duodeno fue mayor $(P<0.05)$, yeyuno e ileón presentaron el mismo tamaño. Los componentes antioxidantes en la pechuga de pollo incrementaron con $400 \mathrm{mg}$ de aceite de orégano por kg de alimento.

Palabras clave: timol, carvacrol, DPPH, aditivo natural.

\section{INTRODUCTION}

Plants contain natural compounds capable of inducing positive effects on poultry productive parameters (Çabuk et al 2006, Arce et al 2008, Abdel et al 2012). Their addition in diets is a growing trend due to the hazards associated with the use of antibiotics, i.e. resistant bacteria that can be transmitted to humans through chicken meat (Castañón 2007). However, the productive response may vary due to the ingredients of the diet, the amount of active components in the additives and the conditions of the experiment (Marković et al 2009, Betancourt et al 2012). Oregano is a plant grown for culinary purposes and generally improves

\footnotetext{
Accepted: 10.03.2017.

aUnidad Académica de Medicina Veterinaria y Zootecnia, Universidad Autónoma de Nayarit, Nayarit, México.

${ }^{\text {b}}$ Campus Irapuato-Salamanca, División de Ciencias de la Vida, Programa de Medicina Veterinaria y Zootecnia, Universidad de Guanajuato, Guanajuato, México.

Corresponding author: F Avila-Ramos; Ex Hacienda El Copal Km. 9, Carretera Irapuato-Silao, C.P. 36500, Irapuato, Guanajuato, México; ledifar@hotmail.com
}

the organoleptic characteristics of the food. Oregano oil is obtained from the leaves of the plant and is used in the industry due to its high antioxidant content. Carvacrol and thymol may represent up to $80 \%$ of the oil (Stefanaki et al 2016). In poultry these compounds can stimulate the digestive processes and protect the polyunsaturated meat fatty acids by decreasing oxidative process rates (Rocha-Guzmán et al 2007, Botsoglou et al 2003, Marčincák et al 2008).

Natural additives can improve the weight gain of poultry, feed intake and feed conversion. Their effects have also been studied on the digestive organs development, gastric secretions, digestibility of dietary nutrients and the integrity of the digestive cells (Hernández et al 2004, Shiva et al 2012). The size of the intestinal villi could serve as an indicator of the general state of the digestive tract because these structures are sensitive to the ingredients contained in the diets (Viveros et al 1994, Betancourt et al 2012). As a result, the size of the intestinal villi could be related with the broiler ability to absorb nutrients and the improvement of growth (Onderci et al 2008, Incharoen et al 2010). Therefore, the aim of the study was to determine the effect of oregano oil dietary supplementation 
on production variables, height of intestinal villi and the meat antioxidant capacity in broilers.

\section{MATERIAL AND METHODS}

\section{POULTRY AND EXPERIMENTAL DIETS}

The research was conducted at the poultry farm of the Professional Academic Unit of Veterinary Medicine and Husbandry at the Universidad Autónoma de Nayarit, located in the municipality of Compostela, Nayarit, Mexico. The methods used in the present experiment were approved by the bioethical committee of this educational center. A total of 480 Ross 308 broilers of both sexes were used; they were fed for 42 days a diet based on corn-soybean meal (table 1) balanced according to the NRC recommendations

Table 1. Chemical composition (\%) of diet.

\begin{tabular}{|c|c|c|}
\hline Ingredient & Initiation & $\begin{array}{c}\text { Grow } \\
\text { Finalization }\end{array}$ \\
\hline Corn & 61.17 & 62.67 \\
\hline Soybean meal & 31.45 & 29.48 \\
\hline Fish Flour & 1.00 & 1.00 \\
\hline Soybean Oil & 3.50 & 3.60 \\
\hline Calcium Bicarbonate (38\%) & 1.43 & 1.52 \\
\hline Dicalcium Phosphate $(18 / 21)$ & 0.78 & 0.95 \\
\hline Salt & 0.30 & 0.30 \\
\hline Vitamin Premix ${ }^{1}$ & 0.01 & 0.01 \\
\hline Vitamin Premix ${ }^{2}$ & 0.02 & 0.02 \\
\hline DL-Methionine & 0.16 & 0.09 \\
\hline HCL-Lysine & 0.18 & 0.06 \\
\hline \multirow[t]{2}{*}{ Xantophylls ${ }^{3}$} & 0.00 & 0.30 \\
\hline & 100.00 & 100.00 \\
\hline \multicolumn{3}{|l|}{ Calculated analysis } \\
\hline Mega calories per kilogram of feed & 3.05 & 3.10 \\
\hline Crude protein & 20.50 & 19.50 \\
\hline Calcium & 1.00 & 0.90 \\
\hline Lysine & 1.25 & 1.10 \\
\hline Methionine + cystine & 0.94 & 0.78 \\
\hline Methionine & 0.50 & 0.40 \\
\hline Available phosphorus & 0.45 & 0.35 \\
\hline Threonine & 0.80 & 0.70 \\
\hline Tryptophan & 0.23 & 0.20 \\
\hline Isoleucine & 0.88 & 0.70 \\
\hline Valine & 0.95 & 0.76 \\
\hline Arginine & 1.25 & 1.05 \\
\hline Linoleic acid & 1.00 & 1.00 \\
\hline
\end{tabular}

1 Quantity in mg per kg feed: vitamin A, 10,000 IU; vitamin $\mathrm{D}_{3}, 2,500$ $\mathrm{IU}$; vitamin $\mathrm{K}_{3}, 2 \mathrm{mg}$; thiamine, $2 \mathrm{mg}$; riboflavin, $7 \mathrm{mg}$; pantothenic acid, $10 \mathrm{mg}$; pyridoxine, $4 \mathrm{mg}$; folic acid, $1 \mathrm{mg}$; Vitamin B12, 0.015 mg; and biotin $0.010 \mathrm{mg}$ (Vipresa $\left.{ }^{\circledR}\right)$, Tepatitlán de Morelos, México.

2 Quantity in mg per kg feed: Se, 0.20; I, 0.30; Cu, 7; Fe, 65; Zn, 75; Mn, 65; y Co, 0.4 (Vipresa $\left.{ }^{\circledR}\right)$, Tepatitlán de Morelos, México.

3 Quantity in mg per kg feed: 90 ppm Tagetes erecta (Florafil-93 Powder, Industrias Vepinsa S.A. de C.V). Los Mochis Sinaloa, México.
(1994). Birds were randomly allocated to four treatments, each with four replications of 30 broilers. The basal diet was supplemented with $0,100,200$ or $400 \mathrm{mg}$ of oregano oil per kg of feed (T-1, T-2, T-3 and T-4, respectively) at the time of diet preparation both in the initiation and growth-finalization stages. Feed and water were provided ad libitum during the 42 days of the experiment; feed intake, weight gain, feed conversion, and mortality rates were weekly recorded.

\section{OREGANO OIL COMPOSITION}

The compounds of oregano oil were identified using a gas chromatograph (Hewlett Packard P-6890, California, USA) coupled to a mass spectrometer (Hewlett Packard 7953, California, USA). The injection port temperature was $240{ }^{\circ} \mathrm{C}$; Hewlett Packard capillary column 5ms® (30 $\mathrm{m}$ long, $0.25 \mathrm{~mm}$ internal diameter and $0.25 \mu \mathrm{m}$ of film thickness, California, USA) was used. The initial oven temperature was $50^{\circ} \mathrm{C}$ for $5 \mathrm{~min}$ and then increased $10^{\circ} \mathrm{C}$ per minute up to $260{ }^{\circ} \mathrm{C}$; Helium was used as carrier gas. The mass spectrometer was operated in scan (range $\mathrm{m} / \mathrm{z}$ $30-550)$ electron ionization mode $(70 \mathrm{eV})$ and flow rate of $1.0 \mathrm{~mL} / \mathrm{min}$.

\section{SACRIFICE AND CHICKEN BREAST SAMPLES COLLECTION}

At the end of the experiment (42 days) two birds per repetition were sacrificed by cutting the jugular vein section and carotid artery following the recommendations of the Official Mexican Standard NOM-033-ZOO-1995. They were bled for 2 minutes, scalded $\left(60^{\circ} \mathrm{C}\right)$ for 120 seconds and manually plucked. Carcasses were cooled in iced water for one hour (about $0{ }^{\circ} \mathrm{C}$ ). Chicken breasts were skinned and after visible fat was removed, they were split in half and the right part was packaged in high vacuum to be frozen $\left(-20^{\circ} \mathrm{C}\right)$ until analysis.

\section{HEIGHT OF INTESTINAL VILLI}

Samples of the duodenum, jejunum and ileum midpoints of two birds per replicate (eight per treatment) were collected for each treatment at 21 and 42 days of age; as duodenum was considered the part from loop along the pancreas up to bile ducts insertion, as jejunum the midpoint between the bile ducts entrance and Meckel's diverticulum, and as ileum the area $10 \mathrm{~cm}$ proximal to the ileocecal junction. Samples were cleaned with distilled water to remove the intestinal contents and fixed in formalin buffered [ 1 liter of $10 \%$ formaldehyde +4.0 $\mathrm{g}$ sodium phosphate monobasic $\left(\mathrm{NaH}_{2} \mathrm{PO}_{4} \cdot \mathrm{H}_{2} \mathrm{O}\right)+6.5 \mathrm{~g}$ dibasic sodium phosphate $\left.\left(\mathrm{Na}_{2} \mathrm{HPO}_{4}\right)\right]$. Tissue samples were embedded in paraffin for cuts to $6 \mu \mathrm{m}$ (Microtome, Leica $\left.{ }^{\circledR}\right)$. Histological sections were stained with hematoxylin and eosin, the height of the intestinal villi was determined measuring from the base of the lamina 
propria to the tip of the villi for duodenum, jejunum and ileum. 15 intestinal villi per sample were measured for each intestinal section and for each bird (Image Analyzer Leco Instruments 2001, Version 2.02).

\section{ANTIOXIDANTS EXTRACTION FROM CHICKEN BREAST}

For the measurement of the antioxidant compounds accumulated in breast, the technique of Tejerina et al (2012) after modifications was used. Six grams of breast were placed in $30 \mathrm{~mL}$ of $80 \%$ ethanol to grind for $20 \mathrm{~s}$ (Blender, Moulinex ${ }^{\circledR}$ ) and each sample was allowed to settle in the dark $\left(25^{\circ} \mathrm{C}\right)$ for $24 \mathrm{~h}$. The resulting solution was stirred and filtered to $0.20 \mu \mathrm{m}$ (Phenex Syringe ${ }^{\circledR}$ ).

Indirect measurement of accumulated antioxidants in breast meat was performed by the DPPH (2,2-diphenyl-1-picrylhydrazyl) radical technique. The DPPH reagent is radical stable in an ethanol solution, has strong violet coloration and its maximum absorbance is obtained at 517 $\mathrm{nm}$. After adding the extract from the chicken breast, the DPPH solution reacts immediately and the color changes to yellow. The antiradical activity based on DPPH. was evaluated with Trolox ${ }^{\circledR}$ (6-hydroxy carboxylic-2, 5, 7, 8-tetrametilcromo, Sigma Aldrich, Toluca, State of Mexico, Mexico) vitamin $\mathrm{E}$ analogous molecule.

A solution of DPPH was prepared at a concentration of $7.4 \mathrm{mg}$ in $100 \mathrm{~mL}$ of ethanol, stirring for 10 minutes in the dark. $100 \mu \mathrm{L}$ of meat extraction were added in $500 \mu \mathrm{L}$ of the DPPH. solution. This solution stirred and allowed to settle in the dark $\left(20^{\circ} \mathrm{C}\right)$ for $30 \mathrm{~min}$, the absorbance of meat was measured with $517 \mathrm{~nm}$. A standard curve was prepared with $500 \mu \mathrm{mol}$ of trolox equivalents per $\mathrm{mL}$.

\section{STATISTICAL ANALYSIS}

Feed intake, weight gain, feed conversion, the size of the intestinal villi and the equivalents of trolox accumulated in breast meat were compared with an experimental design completely randomized using the generalized linear procedure (GLM) of SAS (2000). Comparison of statistical means was performed with the Tukey test. Mortality data were transformed using the Arc sine function and presented as a percentage of weekly mortality. The statistical model used was $Y_{i j=\mu+T i+} \varepsilon_{i j}$. Where: $Y_{i j}$ was feed intake, weight gain, feed conversion, size of the intestinal villi and equivalents of trolox in breast meat, $\mu$ was the measure using a generalized, $\mu$ was the overall mean, ${ }_{T i}$ was the effect of oregano oil added in the diet and $\varepsilon_{i j}$ was the random error.

\section{RESULTS}

\section{OREGANO OIL COMPOSITION}

The identified compounds in oregano oil are presented in table 2 and the chromatogram peaks and retention times are shown in figure 1 . The compounds with the highest
Table 2. Oregano oil composition.

\begin{tabular}{lcc}
\hline Compound & Retention time & Content $(\%)$ \\
\hline P-cymene & 6.01 & 2.90 \\
Eucalyptol & 6.13 & 6.96 \\
$\gamma$-Terpinene & 6.51 & 1.80 \\
Linalool & 7.07 & 0.91 \\
Borneol & 8.14 & 0.90 \\
L-4-terpineol & 8.30 & 1.61 \\
$\alpha$-pinene & 8.47 & 1.31 \\
Rimantadine & 8.63 & 0.57 \\
Thymol methyl ether & 9.05 & 0.95 \\
Thymol & 9.83 & 43.47 \\
Carvacrol & 9.98 & 29.16 \\
Cariophyllene & 11.71 & 5.38 \\
Tetramethyl & 12.15 & 2.96 \\
Acetophenone & 12.35 & 0.40 \\
$\beta$-Caryophyllene & 13.76 & 0.75 \\
\hline
\end{tabular}

percentages in oregano oil were: thymol (43.47\%), carvacrol (29.16\%), eucalyptol (6.96\%), caryophyllene (5.38\%) and tetramethyl $(2.96 \%)$.

\section{PRODUCTION VARIABLES}

Feed intake, weight gain, feed conversion and mortality rates are presented in table 3 . There was no effect of the different levels of oregano oil inclusion in the diet on any of the productive parameters.

\section{HEIGHT OF INTESTINAL VILLI}

Table 4 shows the data on the height of intestinal villi in three and six weeks old chickens. In three weeks, duodenum villi of T-4 group was the largest among the experimental groups, and T-2 and T-3 groups had greater values compared to controls $(P<0.05)$. In jejunum, T-3 and T-4 groups had higher villi compared to T-1 and T-2 groups $(P<0.05)$. Intestinal villi of ileum was higher in T-4 compared to that of the other groups, with a significant difference only between T- 4 and T- 1 broilers $(P<0.05)$. When comparing the height of the intestinal villi in duodenum, jejunum and ileum, duodenum of T-4 group had higher intestinal villi compared to jejunum and ileum $(P<0.05)$.

In six weeks, height of the intestinal villi in duodenum was higher in T-4 group, followed by T-3 and finally by $\mathrm{T}-2$ and $\mathrm{T}-1$ groups $(P<0.05)$. In jejunum, $\mathrm{T}-4$ had also the highest intestinal villi, followed by T-3, T-2and the control group $(P<0.05)$. In ileum, T-4 had higher villi followed by T-3 and finally T-2 and control group $(P<0.05)$. The height of intestinal villi in duodenum was greater compared to jejunum and ileum among all the experimental groups $(P<0.05)$. 


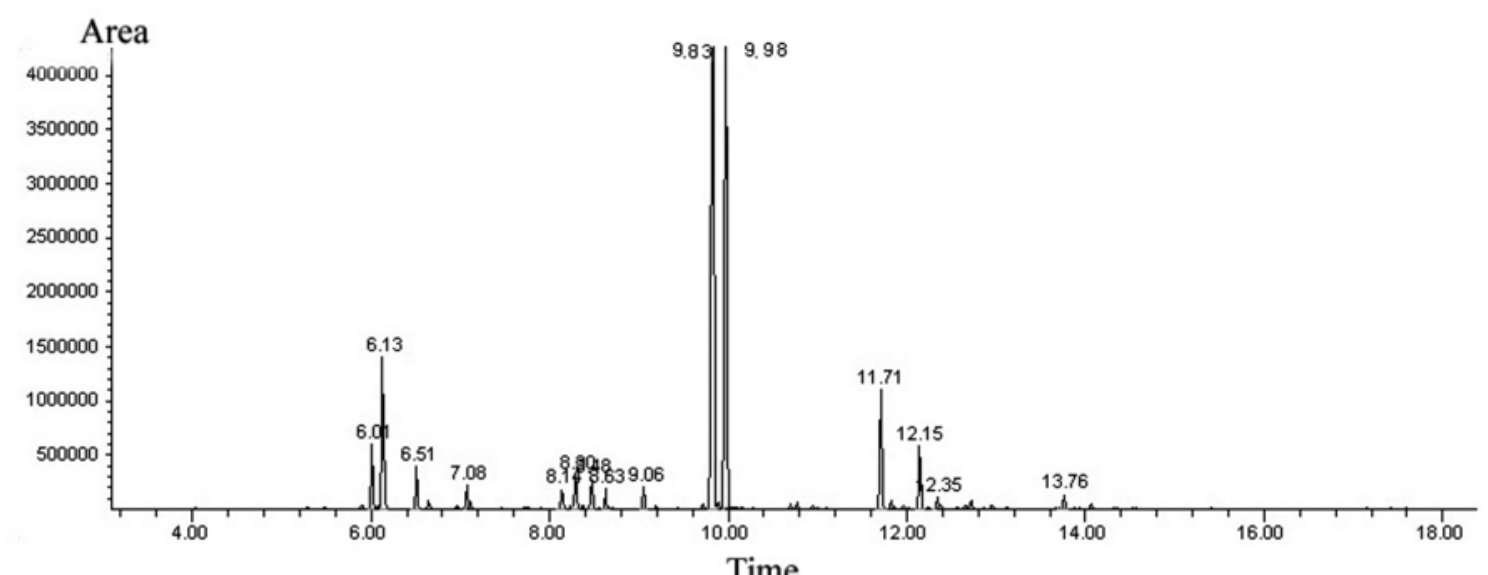

Figure 1. Chromatographic profile of oregano oil.

Table 3. Effect of oregano oil in the production parameters of broilers.

\begin{tabular}{|c|c|c|c|c|c|c|}
\hline \multirow{3}{*}{ Treatment } & \multicolumn{3}{|c|}{ Starter } & \multicolumn{3}{|c|}{ Grower-finisher } \\
\hline & \multicolumn{6}{|c|}{ Week } \\
\hline & 1 & 2 & 3 & 4 & 5 & 6 \\
\hline & \multicolumn{6}{|c|}{ Weekly feed intake $(\mathrm{g})$} \\
\hline $\mathrm{T}-1$ & 141.20 & 314.85 & 485.33 & 643.48 & 808.15 & 1533.55 \\
\hline $\mathrm{T}-2$ & 139.13 & 318.11 & 485.52 & 650.66 & 897.59 & 1502.62 \\
\hline $\mathrm{T}-3$ & 137.00 & 306.24 & 477.45 & 630.85 & 806.80 & 1472.28 \\
\hline $\mathrm{T}-4$ & 135.03 & 310.63 & 467.66 & 624.15 & 853.24 & 1548.00 \\
\hline $\mathrm{P}>\mathrm{F}$ & 0.2710 & 0.3876 & 0.3326 & 0.3696 & 0.3467 & 0.3656 \\
\hline \multirow[t]{2}{*}{ SEM } & 2.04 & 7.83 & 16.66 & 23.2 & 68.8 & 53.4 \\
\hline & \multicolumn{6}{|c|}{ Weight gain $(\mathrm{g}) /$ week } \\
\hline $\mathrm{T}-1$ & 94.43 & 203.60 & 270.05 & 423.94 & 484.94 & 617.18 \\
\hline $\mathrm{T}-2$ & 95.53 & 212.97 & 262.05 & 474.13 & 529.55 & 640.28 \\
\hline $\mathrm{T}-3$ & 88.80 & 207.92 & 258.01 & 435.73 & 458.68 & 597.36 \\
\hline $\mathrm{T}-4$ & 87.38 & 207.61 & 238.99 & 437.78 & 520.40 & 578.19 \\
\hline $\mathrm{P}>\mathrm{F}$ & 0.1499 & 0.6383 & 0.6164 & 0.6089 & 0.6436 & 0.6386 \\
\hline \multirow[t]{2}{*}{ SEM } & 3.33 & 9.31 & 12.03 & 25.82 & 28.88 & 40.63 \\
\hline & \multicolumn{6}{|c|}{ Feed conversion rate $(\mathrm{kg})$} \\
\hline $\mathrm{T}-1$ & 1.50 & 1.55 & 1.80 & 1.54 & 1.65 & 2.49 \\
\hline $\mathrm{T}-2$ & 1.46 & 1.50 & 1.86 & 1.38 & 1.71 & 2.36 \\
\hline $\mathrm{T}-3$ & 1.55 & 1.48 & 1.87 & 1.46 & 1.77 & 2.52 \\
\hline $\mathrm{T}-4$ & 1.56 & 1.51 & 1.99 & 1.43 & 1.65 & 2.71 \\
\hline $\mathrm{P}>\mathrm{F}$ & 0.2710 & 0.6383 & 0.3876 & 0.3278 & 0.3766 & 0.3812 \\
\hline \multirow[t]{2}{*}{ SEM } & 0.04 & 0.05 & 0.10 & 0.07 & 0.13 & 0.1512 \\
\hline & \multicolumn{6}{|c|}{ Mortality (\%) } \\
\hline $\mathrm{T}-1$ & 0 & 0.83 & 0.84 & 0 & 0 & 0 \\
\hline $\mathrm{T}-2$ & 0 & 0.83 & 1.68 & 0 & 1.73 & 0 \\
\hline $\mathrm{T}-3$ & 0 & 0.83 & 2.52 & 0 & 0 & 0 \\
\hline $\mathrm{T}-4$ & 1.66 & 0.84 & 1.70 & 0 & 0 & 0 \\
\hline $\mathrm{P}>\mathrm{F}$ & 0.0728 & 1.000 & 0.6514 & SA & 0.0728 & SA \\
\hline
\end{tabular}

T-1: without oregano oil.

$\mathrm{T}-2=$ oregano oil at $100 \mathrm{mg}$ per $\mathrm{kg}$ of feed.

$\mathrm{T}-3=$ oregano oil at $200 \mathrm{mg}$ per $\mathrm{kg}$ of feed.

$\mathrm{T}-4=$ oregano oil at $400 \mathrm{mg}$ per $\mathrm{kg}$ of feed.

SEM: Standard error of the mean.

SA: Unanalyzed. 
Table 4. Means $(\mu \mathrm{m})$ intestinal villi height in chickens three and six weeks of age.

\begin{tabular}{|c|c|c|c|c|}
\hline \multirow{2}{*}{ Treatment } & Duodenum & Jejunum & Ileum & $P>F^{l}$ \\
\hline & \multicolumn{3}{|c|}{ Week 3} & \\
\hline T-1 & $602.29 \mathrm{c}$ & $564.34 \mathrm{~b}$ & $640.76 b$ & 0.0964 \\
\hline $\mathrm{T}-2$ & $795.31 \mathrm{bx}$ & 606.49 by & $742.50 \mathrm{ab} \mathrm{x}$ & $<0.0001$ \\
\hline $\mathrm{T}-3$ & $864.75 \mathrm{~b}$ & $747.61 \mathrm{a}$ & $764.58 \mathrm{ab}$ & 0.1810 \\
\hline $\mathrm{T}-4$ & 1223.79 ax & 833.31 ay & 843.39 ay & $<0.0001$ \\
\hline $\mathrm{SEM}^{2}$ & 30.22 & 21.90 & 24.47 & \\
\hline \multirow[t]{2}{*}{$P>F$} & $<0.0001$ & $<0.0001$ & 0.0428 & \\
\hline & Week 6 & & & \\
\hline T-1 & $1369.50 \mathrm{cx}$ & 719.69 dy & 878.56 су & $<0.0001$ \\
\hline $\mathrm{T}-2$ & $1322.13 \mathrm{cx}$ & 1034.85 су & $949.41 \mathrm{cy}$ & $<0.0001$ \\
\hline $\mathrm{T}-3$ & $1743.37 \mathrm{bx}$ & 1255.86 by & 1152.39 by & $<0.0001$ \\
\hline $\mathrm{T}-4$ & 2111.31 ax & 1492.53 ay & 1396.21 ay & $<0.0001$ \\
\hline SEM & 40.91 & 38.10 & 32.77 & \\
\hline$P>F$ & $<0.0001$ & $<0.0001$ & $<0.0001$ & \\
\hline
\end{tabular}

T-1: without oregano oil.

$\mathrm{T}-2=$ oregano oil at $100 \mathrm{mg}$ per $\mathrm{kg}$ of feed.

$\mathrm{T}-3=$ oregano oil at $200 \mathrm{mg}$ per $\mathrm{kg}$ of feed.

$\mathrm{T}-4=$ oregano oil at $400 \mathrm{mg}$ per $\mathrm{kg}$ of feed.

${ }^{1} P>F$ Probability.

${ }^{2}$ SEM: Standard error of the mean.

${ }^{a-c}$ Means with different superscript within the same column are statistically different $(P<0.05)$.

${ }^{x-z}$ Means with different superscript within the same row are statistically different $(P<0.05)$.

\section{DETERMINATION OF ANTIOXIDANT CAPACITY IN CHICKEN BREAST}

Table 5 illustrates the antioxidant capacity in breast samples of broilers. In 3 weeks, oregano oil dietary supplementation $(100,200$ or $400 \mathrm{mg})$ increased antioxidant capacity compared to the control $(P<0.05)$. In 6 weeks of age, only chickens of T-4 group had greater antioxidant values compared to the controls $(P<0.05)$.

\section{DISCUSSION}

\section{OREGANO OIL COMPOSITION}

The concentration of oregano oil compounds varies due to the harvest time, cultivation conditions, geographical location, altitude above sea level, climate, genetic variety and plant's phenological age when cut (Abu-Lafi et al 2008). The oregano oil, used in the present study, contained similar levels to those reported in European oregano oils (concentration of thymol and carvacrol at the level of $70 \%$ ), but higher levels than that of Mexican oregano oils (Arana-Sánchez et al 2010).

\section{PRODUCTION VARIABLES}

There was no effect of oregano oil dietary supplementation on the broiler productive parameters. Botsoglou
Table 5. Antioxidant capacity of chicken breast in 3 and 6 weeks of age (expressed as milliequivalents of Trolox per six grams of meat).

\begin{tabular}{lll}
\hline & Week 3 & Week 6 \\
\hline $\mathrm{T}-1$ & $0.694 \mathrm{~b}$ & $0.705^{\mathrm{b}}$ \\
$\mathrm{T}-2$ & $0.725 \mathrm{a}$ & $0.726^{\mathrm{ab}}$ \\
$\mathrm{T}-3$ & $0.727 \mathrm{a}$ & $0.727^{\mathrm{ab}}$ \\
$\mathrm{T}-4$ & $0.727 \mathrm{a}$ & $0.734^{\mathrm{a}}$ \\
$\mathrm{P}>\mathrm{F}^{1}$ & 0.0019 & 0.0187 \\
$\mathrm{SEM}^{2}$ & 0.002 & 0.003
\end{tabular}

T-1: without oregano oil.

$\mathrm{T}-2=$ oregano oil at $100 \mathrm{mg}$ per $\mathrm{kg}$ of feed.

$\mathrm{T}-3=$ oregano oil at $200 \mathrm{mg}$ per $\mathrm{kg}$ of feed.

$\mathrm{T}-4=$ oregano oil at $400 \mathrm{mg}$ per $\mathrm{kg}$ of feed.

${ }^{1} P>F$ Probability

${ }^{2}$ SEM: Standard error of the mean.

${ }^{a-b}$ Means with different superscript within the same column are statistically different $(P<0.05)$.

et al (2002) and Marčincák et al (2008) obtained similar results by adding 50, 100, 200 and $500 \mathrm{mg}$ of oregano oil per $\mathrm{kg}$ of feed. The amount of thymol and carvacrol in oregano oil has been linked to weight gain, since these compounds stimulate the secretion of bile, pancreas and digestive enzymes leading to an improved absorption of nutrients in the intestinal lumen (Russo et al 1998, Lee at al 2004, Wang and Peng 2008). Although, stimulation 
of secretion in the digestive system could possibly be an effect of oregano oil, it was not associated with an improvement of the productive parameters in the present study. On the other hand, Nihat et al (2005), Betancourt et al (2012) and Freitas et al (2013) reported improvement in production variables due to the presence of thymol in oregano oil. Similar results were reported with various combinations of Mexican oregano oil (Vázquez et al 2015). In addition, the diet ingredients could alter the effect of the components of oregano oil as reported by Uni et al (1998) and Langhout et al (2000), who mentioned that the digestibility of the ingredients and the environmental conditions could play an important role and influence the effects of added natural additives. For example, the use of a less digestive or contaminated feed could result in a greater effect of natural additives on the parameters of broilers.

\section{HEIGHT OF INTESTINAL VILLI}

The intestinal villi height depends on the balance between proliferation, migration and cell apoptosis. The main function of the villi is the absorption of nutrients, an activity which is partially dependent on its size. In addition, villi can be considered as intestinal health indicator (Uni et al 1998, Laudadio et al 2012). Natural additives improve the epithelium surface structure and increase the enterocytes size (Wang and Peng 2008, Incharoen et al 2010).

The highest villi appeared in 42 days old chickens, and the size in duodenum, jejunum and ileum was greater by 16,22 and $70 \%$, respectively, compared to that reported by Chiang et al (2010) and Zavarize et al (2012). Other researchers report no morphological changes at doses of $500 \mathrm{mg}$ of oregano oil per $\mathrm{kg}$ of feed (Onderci et al 2008, Betancourt et al 2012, Emami et al 2012, Laudadio et al 2012, Wu et al 2013). Olnood et al (2015) mentioned that additives could favor the development of bacteria and improve growth of the anatomical structures. However, the variation of components in oregano oil and diet are factors that can modify these effects. Chiang et al (2010) and Sayrafi et al (2011) report that the villi height increases with the amount of oregano oil in the feed, an effect that was also observed in the experiment both for 3 and 6 week old chickens.

\section{ANTIOXIDANT CAPACITY OF CHICKEN BREAST}

The height of intestinal villi was associated with the accumulation of antioxidant compounds in the breast meat, since villi height influences the absorption of nutrients (Chiang et al 2010). Chickens receiving a diet with 400 $\mathrm{mg}$ of oregano oil per $\mathrm{kg}$ feed had higher absorption and accumulation of oregano compounds and its metabolites in their their muscle fibers (Uni et al 1998). The amount of compounds accumulated in the breast meat was higher in chickens that received higher levels of oregano oil.
It can be concluded that oregano oil that contained $43 \%$ thymol and $29 \%$ carvacrol resulted in no effect on broilers' productive parameters at the doses of 100, 200 or $400 \mathrm{mg}$ per $\mathrm{kf}$ of feed. However, by increasing the dose of oregano oil, height of the intestinal villi was also increased. The larger size of the villi appeared in duodenum, jejunum and ileum in six weeks old broilers. Finally, antioxidant capacity of breast meat was higher in chickens fed with the oregano supplemented diets compared to the controls.

\section{ACKNOWLEDGEMENTS}

The authors acknowledge the research funding Program for Professional Development Teaching DSA /103.5/15/10902 from the Public Education Secretary.

\section{REFERENCES}

Abdel WA, Kehraus S, Hippenstiel F, Südekum KH. 2012. Effects of thyme and oregano on growth performance of broilers from 4 to 42 days of age and on microbial counts in crop, small intestine and caecum of 42-day-old broilers. Anim Feed Sci Technol 178, 198-202.

Abu-Lafi S, Odeh I, Dewik H, Qabajah M, Hanus L, et al. 2008. Thymol and carvacrol production from leaves of wild Palestinian majorana syriaca. Bioresource Technol 99, 3914-3918.

Arana-Sánchez A, Estarrón-Espinosa M, Obledo-Vázquez EN, PadillaCamberos E, Silva-Vázquez R, et al. 2010. Antimicrobial and antioxidant activities of Mexican oregano essential oils (Lippia Graveolens H. B. K.) with different composition when microencapsulated in beta-cyclodextrin. Lett Appl Microbiol 50, 585-590.

Arce MJ, Ávila GE, López CC. 2008. Comportamiento productivo y cambios morfológicos en vellosidades intestinales del pollo de engorda a 21 días de edad con el uso de paredes celulares del Saccharomyces cerevisiae. Vet Méx 39, 223-228.

Betancourt LL, Ariza CJ, Afanador G. 2012. Effects of supplementation with oregano essential oil on ileal digestibility, intestinal histomorphology, and performance of broiler chickens. Revista Colombiana de Ciencias Pecuarias 172, 240-251.

Botsoglou NA, Christaki E, Fletouris DJ, Florou PP, Spais AB. 2002. The effect of dietary oregano essential oil on lipid oxidation in raw and cooked chicken during refrigerated storage. Meat Sci 62, 259-265.

Botsoglou NA, Grigoropoulou SH, Botsoglou E, Govaris A, Papageorgiou G. 2003. The effects of dietary oregano essential oil and $\alpha$-tocopheryl acetate on lipid oxidation in raw and cooked turkey during refrigerated storage. Meat Sci 65, 1193-2000.

Çabuk M, Bozkurt M, Alçiçek A, Akbap Y, Küçükyýlmaz K. 2006. Effect of a herbal essential oil mixture on growth and internal organ weight of broilers from young and old breeder flocks. S Afr J Anim Sci 36, 135-141.

Castañón JIR. 2007. History of the use of antibiotic as growth promoters in european poultry feeds. Poult Sci 86, 2466-2471.

Chiang G, Lu WQ, Piao XS, Hu JK, Gong LM, et al. 2010. Effects of feeding solid-state fermented rapeseed meal on performance, nutrient digestibility, intestinal ecology and intestinal morphology of broiler chickens. Asian Austral J Anim 23, 263-271.

Emami NK, Samie A, Rahmami HR, Ruiz-Feria CA. 2012. The effect of peppermint essential oil and fructooligosaccharides, as alternatives to virginiamycin, on growth performance, digestibility, gut morphology and immune response of male broilers. Anim Feed Sci Technol 175, 57-64.

Freitas SZ, Ribeiro DS, Alves MRR, Aparecida MS, Santos MA, Luiz GC. 2013. Oregano essential oil as antimicrobial agent in broilers diet. Arch Vet Sci 18, 01-07. 
Hernández F, Madrid J, García V, Orengo J, Megías MD. 2004. Influence of two plant extracts on broilers performance, digestibility, and digestive organ size. Poult Sci 83, 169-174.

Incharoen T, Yamauchi K, Ericawa T. 2010. Histology of intestinal villi and epithelial cells in chickens fed low protein or low fat diets. Ital J Animal Sci 9, 429-434.

Langhout DJ, Schutte JB, De Jong J, Sloetjes H, Verstegen MW, et al. 2000. Effect of viscosity on digestion of nutrients in conventional and germ-free chicks. Br J Nutr 83, 533-540.

Laudadio V, Passantino L, Perillo A, Lopresti G, Lopresti G, et al. 2012. Productive performance and histological features of intestinal mucosa of broiler chickens fed different dietary protein levels. Poul Sci 91, 265-270.

Lee KW, Everts H, Beynen AC. 2004. Essential oils in broiler nutrition. Int J Poult Sci 3, 738-752.

Marčincák S, Cabadaj R, Popelka P, Soltysova L. 2008. Antioxidative effect of oregano supplemented to broilers on oxidative stability of poultry meat. Slov Vet Res 45, 61-66.

Marković R, Šefer D, Krstić M, Petrujkić B. 2009. Effect of different growth promoters on broiler performance and gut morphology. Arch Med Vet 41, 163-169.

Nihat OE, Güler T, Çiftçi M, DalkIlIç B, Gülcihan ÜS. 2005. The effect of an essential oil mix derived from oregano, clove and anise on broiler performance. Int J Poult Sci 4, 879-884.

NRC, National Research Council. 1994. Nutrient requirements of poultry. $9^{\text {th }}$ ed. Natl. Acad. Press, Washington, DC, USA.

Olnood CG, Beski SSM, Lji PA, Choct M. 2015. Delivery routes for probiotics: effects on bird performance, intestinal morphology and gut microflora. Animal Nutrition 1, 192-202.

Onderci M, Sahin N, Cikim G, Aydin A, Ozercan I, et al. 2008. Glucanaseproducing bacterial culture improves performance and nutrient utilization and alters gut morphology of broilers fed a barley-based diet. Anim Feed Sci Technol 146, 87-97.

Rocha-Guzmán NE, Gallegos-Infante JA, González-Laredo RF, RamosGómez M, Rodríguez-Muñoz ME, et al. 2007. Antioxidant effect of oregano (Lippia berlandieri v. Shauer) essential oil and mother liquors. Food Chem 102, 330-335.

Russo MG, Galletti C, Bocchini P, Carnacini A. 1998. Essential oils chemical composition of wild populations of Italian oregano spice
(Origanum vulgare ssp, hirtum (Link) Lestwart): A preliminary evaluation of their use in chemotaxonomy by cluster analysis. I. inflorescences. J Agric Food Chem 46, 3741-3746.

SAS, Statistical Analysis System. 2000. SAS version 6.0. SAS Institute Inc., Cary, NC, USA.

Sayrafi R, F Soltanalinejad, R Shahrooz, S Rahimi. 2011. Effects of butyric acid glycerides and antibiotic growth promoter on the performance and intestinal histomorphometry of broiler chickens. J Food, AgricEnviron 9, 285-288.

Shiva C, Bernal S, Sauvain M, Caldas J, Kalinowski J, et al. 2012. Evaluación del aceite esencial de orégano (Origanum vulgare) y extracto deshidratado de jengibre (Zingiber officinale) como potenciales promotores de crecimiento en pollos de engorde. Rev Inv Vet Perú 23, 160-170.

Stefanaki A, Cook KM, Lanaras T, Kokkini S. 2016. The Oregano plants of Chios Island (Greece): Essential oils of Origanum onites L. growing wild in different habitats. Ind Crop Prod 82, 107-113.

Tejerina D, García-Torres S, Cabeza de Vaca M, Vázquez FM, Cava R. 2012. Study of variability in antioxidant composition and fatty acids profile of Longissimus dorsi and Serratus ventralis muscles from Iberian pigs reared in two different Montanera season. Meat Sci 90, 414-419.

Uni Z, Ganot S, Sklan D. 1998. Posthatch development of mucosal function in the broiler small intestine. Poult Sci 77, 75-82.

Vázquez RS, Meléndez LAD, Santellano EE, Rodríguez CM, Villalobos GV, et al. 2015. Performance of broiler chickens supplemented with Mexican oregano oil (Lippia berlandieri Schauer). R Bras Zootec 44, 283-289.

Viveros A, Brenes A, Pizarro M, Castaño M. 1994. Effect of enzyme supplementation of a diet based on barley, and autoclave treatment, on apparent digestibility, growth performance and gut morphology of broilers. Anim Feed Sci Technol 48, 237-251.

Wang JX, Peng KM. 2008. Developmental morphology of the small intestine of african ostrich chicks. Poult Sci 87, 2629-2635.

Wu QJ, Zhou YM, Wu YN, Wang T. 2013. Intestinal development and function of broiler chickens on diets supplemented with clinoptilolite. Asian-Australas J Anim Sci 26, 987-994.

Zavarize KC, Sartori JR, Gonzalez E, Pezzato AC. 2012. Morphological changes of the intestinal mucosa of broilers and layers as affected by fasting before sample collection. Rev Bras Cienc Avic 14, 21-25. 
